KINGA KRAWIECKA

Wydział Nauk Pedagogicznych

Uniwersytet Kardynała Stefana Wyszyńskiego

Warszawa
Forum Pedagogiczne $2016 / 1$

Wpłynęło: 17.11.2015

Zatwierdzono do druku: 13.04.2016

\title{
DZIAŁALNOŚĆ ARTYSTYCZNA UCZNIÓW Z NIEPEŁNOSPRAWNOŚCIĄ INTELEKTUALNĄ I STUDENTÓW - JAKO ZAPRZECZENIE ARTETERAPII
}

Streszczenie: W opracowaniu podjęłam próbę przedstawienia działalności artystycznej uczniów z niepełnosprawnością intelektualną i studentów w wymiarze swobodnej, nieprofesjonalnej twórczości plastycznej, muzycznej oraz teatralnej. Przybliżyłam możliwości wykorzystania potrzeby ekspresji, której swoistość przeciwstawia się charakterowi arteterapii. Treść prezentowanego tekstu uzupełniłam osobistymi spostrzeżeniami i przemyśleniami wynikającymi z pracy artystycznej z osobami z niepełnosprawnością intelektualną.

Słowa kluczowe: twórczość, aktywność twórcza osób z niepełnosprawnością intelektualną, arteterapia, plastyka, muzyka, teatr

Twórczy charakter działalności człowieka determinuje w moim mniemaniu postawę filozoficzną. Owa postawa czyni go zdolnym do zadawania pytań, a spełnia się w mierzeniu się z nimi i odkrywaniu nowych odpowiedzi. W postawie pytającego jest pewien namysł, refleksja nad tym, co fundamentalne. Człowiek twórczy, zmagając się ze sobą, dokonuje autorefleksji, dzięki której jest zdolny modyfikować osobisty pogląd na świat.

Twórczość, którą chcę przedstawić, nie odsłania działalności artystycznej w znaczeniu profesjonalnym - świadomym i celowym, wolnym i odpowiedzialnym tworzeniu dzieł sztuki. Poza tym nie ukazuję działalności artystycznej jako arteterapii, której jednoznacznym celem jest wyrażanie i przepracowywanie trudności, z jakimi zmaga się jednostka, tym bardziej że o specyfice arteterapii „decyduje jej kontekst psychoterapeutyczny wraz z właściwą mu refleksją oraz czynnikami leczącymi” (Stańko-Kaczmarek 2013, s. 34).

Zatem co jest fundamentalnym celem niniejszego opracowania? Otóż jest nim deskrypcja swobodnej, nieprofesjonalnej twórczości artystycznej (plastycznej, muzycznej, teatralnej) uczniów z niepełnosprawnością intelektualną oraz studentów Wydziału Nauk Pedagogicznych Uniwersytetu Kardynała Stefana Wyszyńskiego w Warszawie, rozpatrzenie aktywności o charakterze pedagogicznym dwóch 
środowisk: szkolnego i akademickiego, które poprzez działania artystyczne tworzą wspólne dzieło wzajemnego dialogu, bezpośredniej inspiracji i życiowej integracji. Zatem opisane działania artystyczne uczniów i studentów stanowić mają podstawę normalizacji funkcjonowania, a nie terapii.

\section{Twórczość niepełnosprawnych intelektualnie - twórczość nieunikniona}

Kluczowe pojęcie twórczości może mieć trzy historyczne ujęcia. Ewolucyjnie najstarsze głosi, że odnosi się ona wyłącznie do działalności Boga - stwórcy świata, znajdując się tym samym poza kontrolą człowieka. W okresie od odrodzenia do wieku XIX twórczość ma swoje źródło w sztuce, w działalności artystów tworzących rzeczy nowe - w genetycznie dziedziczonym geniuszu. Wiek XX głosi natomiast, że odnosi się ona do wszystkich ludzi i różnych sfer ich działań: sztuki, nauki, techniki, aktywności społecznej, autokreacji (Szmidt 2013). Ludzie natomiast „charakteryzują się pewnym poziomem twórczości, podobnie jak wykazują się określonym stopniem inteligencji, i że środowisko, w którym człowiek się rozwija, odgrywa znaczącą rolę w ujawnianiu się tej twórczości" (Dacey, Lennon 1998, s. 15).

W zależności od teoretycznego i metodologicznego rozumienia pojęcia twórczości psychologowie, pedagogowie, socjologowie, filozofowie, historycy sztuki różnorako akcentują istotę tego zjawiska. Czteroaspektowa interpretacja twórczości wyłania (Szmidt 2013):

1. twórczość jako wytwór (aspekt atrybutywny);

2. osobę twórcę (aspekt personologiczny);

3. proces psychiczny (aspekt procesualny);

4. czynniki zewnętrzne warunkujące proces tworzenia (aspekt stymulatorów inhibitorów).

Atrybutywny aspekt twórczości sprowadza się do dwóch kryteriów, a mianowicie nowości i użyteczności, które ujmuje się w kontekście wartości dzieła. „W moim przekonaniu nie może być wytworem twórczym produkt o charakterze destrukcyjnym, niemoralnym, nieprawnym. Nowość jest cechą konstytutywną produktu twórczości, wartość jest zaś cechą różnicującą, dzielącą wytwory na dobre i złe. [...] W tym sensie twórcze są - w moim rozumieniu - te wytwory lub działania, które przyczyniają się do osiągnięcia wartości związanych z urzeczywistnianiem dobra i piękna oraz poszukiwaniem prawdy [...]. Takie postrzeganie wytworu procesu twórczego wiąże się z perspektywą aksjologiczno-wychowawczą przyjętą w pedagogice twórczości, a związaną z humanistycznym rozumieniem twórczości jako działalności wartościowej dla twórcy i środowiska, w którym żyje i działa" (Szmidt 2013, s. 99-100). Twórczość w wymiarze atrybutywnym sprowadza się do wielu określeń, oznaczających różne jej poziomy, a mianowicie:

- drugorzędna i poważna;

- wybitna i codzienna;

- praktyczna, wynalazcza i innowacyjna; 
- pospolita i emergencyjna (Szmidt 2013).

Analizując powyższe szczeble twórczości, można by rzec, że każdy człowiek ma predyspozycje do tworzenia, co więcej, Abraham Harold Maslow pisał, że owe twórcze predyspozycje umożliwiają proces samorealizacji (Maslow 1986), a Wifredo Lam, jeden z czołowych malarzy XX wieku, nadmieniał: „każdy wysiłek twórczy tylko wtedy może dać dobre wyniki, kiedy powstaje z głębokiej wewnętrznej potrzeby wypowiadania się i wyraża osobisty stosunek do rzeczywistości. Tylko w takim wypadku powstaje indywidualna koncepcja obrazu i dzieło kształtuje się w sposób żywy i niepowtarzalny" (Lam 1960, s. 5).

Personologiczny aspekt twórczości koncentruje się na konstruowaniu pytań o cechy charakteryzujące jednostkę, która tworzy, i próbie poszukiwania na nie odpowiedzi. „Jacy ludzie tworzą, jakie właściwości psychiczne są warunkiem koniecznym osiągnięć twórczych, jaki jest związek twórczości z cechami indywidualnymi (inteligencją, stylami poznawczymi, neurotycznością itd.) i zdrowiem psychicznym, czy istnieje jeden syndrom cech osobowości twórczej i czy można mówić o specyficzności cech składających się na tę osobowość" (Szmidt 2013, s. 102). Ponadto w podmiotowym wymiarze twórczości należy zaznaczyć potrzeby jednostki. Pierwszą z nich jest potrzeba obecności, ściśle związana z doświadczaniem tożsamości. „Widz, słuchacz kontaktując się z dziełem twórcy, uznaje jego wypowiedź za istotną, niekoniecznie zgadza się z nią, ale bierze ją pod uwagę. Jeśli odnajdzie twórcę, z którym może się zgodzić, dzieło, z którym może się identyfikować - uzyskuje zaspokojenie potrzeby tożsamości” (Krasoń, Mazepa-Domagała 2003, s. 11). Drugą jest potrzeba uczestniczenia, dająca możliwość poznania nowej rzeczywistości i tworzenia sztuki, poprzez którą człowiek jest kształtowany. Okazuje się zatem, że „zaistnienie tej potrzeby jest jedną z bardziej znaczących przyczyn powodzenia niektórych dziedzin sztuki, możliwość obserwowania zmagań przedstawionego w niej konstruktu bohatera przynosi uczucie ulgi, zaciekawia i skłania do podążania za nim, zatem i do kontynuowania kontaktu z produktem twórczej ekspresji” (Krasoń, Mazepa-Domagała 2003, s. 12). Trzecią jest potrzeba ujawniania siebie, która zachodzi podczas tworzenia dzieła, komponowania form i znaczeń. Warto podkreślić nie sens terapeutyczny aktywności twórczej podmiotu, ale czynnik motywacyjny, który polega na pragnieniu zatrzymania przeżyć tworzącego, by mogły zostać odczytane przez innych. „Akt tworzenia dzieła jest obcowaniem $\mathrm{z}$ samym sobą, ale obcowaniem niejako z myślą o dopuszczeniu do tej specyficznej intymności osób trzecich - odbiorców" (Krasoń, Mazepa-Domagała 2003, s. 13). Podmiotowy wymiar twórczości wyrasta zatem z potrzeb jednostki i tym potrzebom służy. Jest w pełni zintegrowany z jej odczuciami, a w związku z tym pozwala na prawdziwe, adekwatne wyrażanie siebie. Sądzę, że każdy rodzaj sztuki poprzez odwoływanie się do potrzeb jednostki stanowi nie tyle ważny element terapii, co składową jej prawdziwie głębokiego życia, skierowanego ku transcendencji.

Procesualne rozumienie twórczości koncentruje się na wytworze, który nie zawsze odpowiada wymaganiom teoretycznym czy metodologicznym, jednakże powstaje 
w wyniku procesów - psychicznych, intelektualnych, w które zaangażowane są emocje, uczucia, motywacja, wyobraźnia. Podstawowe pytania w tym ujęciu brzmią: „Jak powstaje twórczy pomysł? Jakie procesy psychiczne, intelektualne, emocjonalne, motywacyjne oraz behawioralne powodują narodzenie się nowego i wartościowego produktu?" (Szmidt 2013, s. 101). Próba zastanowienia się, w jaki sposób człowiek tworzy, powoduje wyłonienie się wielu teorii twórczości, również tej, która neguje wyjątkowość procesu twórczego, przypisując operacjom intelektualnym biorącym udział w akcie twórczym cechy normalności i zwyczajności (Szmidt 2013). „Wiele badań psychologicznych potwierdza zwyczajność procesów intelektualnych odpowiadających za efektywność myślenia twórczego, deprecjonując tym samym różnorodne koncepcje olśnienia, myślenia lateralnego czy innych nadzwyczajnych aktów twórczych, do których zdolni są jakoby tylko geniusze" (Szmidt 2013, s. 101). Wśród procesów psychicznych, intelektualnych, posiadających tę samą naturę, a więc wspólnych dla twórczości profesjonalnej i nieprofesjonalnej, wymienia się między innymi: proces poznawania zmysłowego, przetwarzania informacji oraz procesy pamięciowe (Popek 2010).

Proces tworzenia warunkuje więc „ogół czynników wpływających na podejmowanie, treść, intensywność, przebieg i rezultaty działań twórczych” (Szmidt 2013, s. 103-104). Wyróżnia się wśród nich czynniki wewnętrzne (podmiotowe), takie jak: wiedza, motywacja, system wartości, sprawności intelektualne, oraz czynniki zewnętrzne (pozapodmiotowe), sięgające kontekstu społecznego, kulturowego, technicznego (Szmidt 2013). „Działalność twórcza ma zawsze swój kontekst, odbywa się w szerszym układzie warunków (materialnych, przestrzennych, społecznych i kulturowych), które są dla innowatora środowiskiem jego działalności (pracy)" (Schulz 1990, s. 329). Czynniki zewnętrzne mające wpływ na proces twórczy określa się jako stymulatory, które go dynamizują i usprawniają, lub jako inhibitory, które hamują i utrudniają jego przebieg. Wśród nich wymienia się:

- właściwości środowiska wychowawczego (rodziny, szkoły, instytucji kulturalnych);

- cechy zadań rozwojowych, jakie stawia się przed jednostką w toku edukacji i wychowania (Szmidt 2013).

Wszystkie powyższe aspekty interpretowania twórczości należy traktować łącznie, ujmując je w związek wielostronny. „Komfort psychiczny i pobudzona wyobraźnia zrobiły swoje, reszta powstała sama $\mathrm{z}$ tych wartości, które w nich tkwią, takich jak żywa wrażliwość, chęć tworzenia i sposób patrzenia na świat, sposób nieprzeżarty przez schematyzm dydaktyczny czy panujące mody. Mnie się zdaje, że gdyby ktoś zechciał się zagłębić w badania nad twórczością osób z upośledzeniem umysłowym, to być może wiele dowiedziałby się o istocie procesu tworzenia w ogóle, o tym, jak powstaje zamysł, co jest niezbędne, aby człowiek tworzył w swobodzie, może nawet o widzeniu kolorów, bo oni bywają wspaniałymi kolorystami, choć nie znają nazw kolorów” (Aumer 1995, s. 9).

Działalność artystyczna osób z niepełnosprawnością intelektualną to niewątpliwie bardzo złożony fenomen, którego swoistość nie powinna wymuszać litościwego, 
odmiennego spojrzenia. Aktywność artystyczna i ujawnianie jej efektów nie musi przybierać charakteru terapii czy rehabilitacji, czasem może ujawniać instrumentalny, zadaniowy sens pracy twórczej. Osoba z niepełnosprawnością intelektualną jak wszyscy odbiera bodźce ze świata zewnętrznego, rozpoznaje je, interpretuje, uzupełnia o wciąż nowe - zatem dostrzega, słyszy, smakuje, czuje, budując obraz świata. „Człowiek jest twórczy, gdy nie ogranicza się do powtarzania, naśladowania, gdy daje coś z siebie i od siebie. Tak rozumianej twórczości jest wiele: nie tylko w tym, co człowiek ze światem robi i co o nim myśli, ale też w tym, jak go widzi. I nie może być inaczej. Człowiek, czy chce, czy nie, musi uzupełniać otrzymywane ze świata bodźce, musi formować swój obraz świata, wrażenia bowiem nie są kompletne i ukształtowane, wymagają scalenia. Ta twórczość, którą uzupełniamy o otrzymane z zewnątrz dane, jest powszechna. Rzec można, że człowiek jest skazany na twórczość" (Szmidt 2013, s. 94). Każda osoba, również z niepełnosprawnością intelektualną, ma szansę urzeczywistniania swoich możliwości rozwojowych, realizacji własnego potencjału twórczego. Może okazywać emocje, uobecniając tym samym własną osobowość, by móc regulować kontakt z otoczeniem, sygnalizować swoje potrzeby oraz preferowane wartości. Zatem dostrzegając, słysząc, smakując, czując, każdy z nas uczestniczy w nieuniknionym procesie tworzenia, wysiłku nieustannego wyrażania siebie. „Twórczość jest przejawem potrzeby pełniejszego życia. [...] Zapominamy, że potrzeba tworzenia jest tak podstawowa jak oddychanie. [...] Każdy akt twórczy jest podobny do procesu oddychania składającego się z wdechu i wydechu" (Zinker 1991, s. 9-13).

Działania artystyczne są niewątpliwie tym obszarem aktywności, który sprzyja doświadczaniu osobistego potencjału twórczego i wspomaga umiejętność budowania bądź zmieniania świata według własnego niepowtarzalnego pomysłu.

\section{Osoba $\mathrm{z}$ niepełnosprawnością intelektualną w różnych formach działalności artystycznej}

Odbierając, analizując i uzupełniając bodźce ze świata zewnętrznego, każdy z nas buduje własną strukturę rzeczywistości, a więc w sposób naturalny uczestniczy w procesie twórczym. Tak pojmowana twórczość może zawierać się w każdej aktywności człowieka - aktywności specyficznej, procesualnej. „Kategoria dążenia opisująca specyficzny, długofalowy sposób działania jest konieczna nie tylko do osiągnięcia czegoś określonego i ważnego, ale także stanowi ważny element osobistej satysfakcji z życia. [...] Rezygnacja z dążeń i przyzwolenie na bycie spełnianym przez okoliczności swego życia powoduje uprzedmiotowienie człowieka, utożsamienie się go jako obszaru oddziaływań świata, co nie pozwala na uzyskanie autonomicznej tożsamości, blokuje indywidualną twórczość" (Mrozkowiak-Nastrożna 2006, s. 58).

Z pojęciem szeroko rozumianej twórczości silnie wiąże się zagadnienie działania artystycznego czy też aktywności artystycznej. Aktywność artystyczna definiowana jest jako „charakterystyczny stan i podstawowa cecha jednostki, choć 
niejednakowo rozwinięta, powodująca, że podejmujący ją może aktywnie regulować swoje stosunki ze środowiskiem twórczym, adekwatnie przystosowywać się do niego, jak też wywoływać określone indywidualne zmiany w tym otoczeniu" (Ploch 2014, s. 21). Zatem nie istnieje poza człowiekiem, a jest obecna w nim samym. Jak przekonuje Hanna Krauze-Sikorska: „Człowiek jest istotą sterowaną nie przez sytuacje zewnętrzne, lecz przez wewnętrzne obrazy świata. Staje się tym samym jednostką kształtowaną nie tyle przez czynniki zewnętrzne, ile kształtującą siebie przez czynne - zarówno poznawcze, jak i działaniowe - odnoszenie się do świata i samego siebie. Człowiek intencjonalny, samosterowny, autonomiczny to istota, której życiowa aktywność zdeterminowana jest nie przez czynniki i warunki świata zewnętrznego, lecz przez to, w jaki sposób dane doświadczenie odzwierciedlone zostanie w jego umyśle" (Krauze-Sikorska 2006, s. 109).

Mianem aktywności artystycznej uczniów z niepełnosprawnością intelektualną oraz studentów nie określam nowej jakości powstałej z połączenia fazy działania i fazy refleksji. Taka integracja stanowi o specyfice arteterapii, której istotą jest zmiana, jaka ma się dokonać w jednostce. Działań artystycznych, o jakich piszę, nie traktuję jako narzędzia poprawy czy modyfikacji funkcjonowania emocjonalnego, zmiany perspektywy myślenia, zachowania, odczuwania. Zależy mi bowiem na ukazaniu twórczych działań artystycznych, które są ściśle związane z tworzeniem i ekspresją artystyczną (plastyczną, muzyczną, teatralną), a ich pozytywny wpływ na dobrostan człowieka jest sprawą wtórną, a nawet skutkiem ubocznym wobec silnej potrzeby tworzenia. Bo czy każdy udział jednostki z niepełnosprawnością intelektualną w kreowaniu wydarzenia artystycznego mamy prawo nazywać terapią/arteterapią? A jeśli tak, to dlaczego osoba nieobarczona niepełnosprawnością intelektualną, która maluje, tańczy, gra na scenie, nie jest postrzegana w ten sam sposób? Ale jako taka, która po prostu uprawia sztukę, a celem jej działania jest sama kreacja, a nie pomoc sobie? Chcę dobitnie zaznaczyć, że choć można dostrzec różnicę pomiędzy twórczością osób z niepełnosprawnością intelektualną a twórczością osób nią niedotkniętych, to sztuka małych, konkretnych zadań jest nie mniej ważna społecznie niż sztuka wielkiej sceny, dotykająca najszerszych spraw społecznych i moralnych.

Ograniczając się do ogólnej prezentacji form aktywności artystycznej, przedstawię wybrane ich odmiany: działalność plastyczną, muzyczną i teatralną, które w łączności ze sobą stworzyły rzeczywistość dzieła artystycznego zatytułowanego „Majówka Aniołów”.

W niniejszym artykule aktywność plastyczną, muzyczną i teatralną osób z niepełnosprawnością intelektualną oraz studentów traktuję jako zabawę twórczą, która jest przede wszystkim cechą wrodzoną każdej jednostki. Jest ona przejawem osobistej aktywności twórczej, wykonywanej z przyjemności i dla przeżycia przyjemności, „opartej na udziale wyobraźni, która tworzy nową rzeczywistość” (Okoń 1992, s. 154). Twórczość zarówno plastyczna, muzyczna, jak i teatralna w omawianym przykładzie polegała głównie na aktywności własnej jednostki z niepełnosprawnością intelektualną, ale była wsparta działaniem animatorów-studentów. 
Uczestnicy tworzyli prace plastyczne techniką malarską, wydobywali dźwięki na instrumentach perkusyjnych oraz kreowali własne sceny teatralne z użyciem technik naśladowania czynności. Podejmowali działania artystyczne, malując, muzykując, manipulując materiałem przestrzennym, werbalizując treści, przyjmując nowe role. Pod ich wpływem uczestnicy mieli okazję „dzielić zjawiska i rzeczy na przykre bądź przyjemne. [...] Warto pokusić się zatem o stwierdzenie, że aktywność twórcza wyrasta z najsilniejszej, wewnętrznej motywacji i staje się naturalną drogą rozwoju każdego człowieka" (Ploch 2014, s. 51).

Plastyka jest obszarem głęboko nasyconym emocjami, przeżyciami, uczuciami i wzruszeniami, których nie da się przełożyć na język werbalny. Może dlatego jest tak ceniona przez osoby z niepełnosprawnością intelektualną. Malując z pomocą studentów barwne majówkowe anioły wielkich formatów, miały one ogromną radość z tworzenia - tworzenia bezinteresownego. Animatorzy-studenci często myśleli o tym, co stanie się z ich wspólnym dziełem. Jaki będzie jego odbiór. Niepełnosprawni zaś mieli czystą radość z tworzenia, a tym samym wyrażania osobistych wyobrażeń, bo „twórcza aktywność plastyczna jest samodzielną realizacją przez człowieka, za pomocą tworzywa plastycznego, wizji świata rzeczywistego, widzianego jego oczami, bądź własnego świata wyobraźni. Jest to przeniesienie świata stworzonego w umyśle ludzkim do świata plastyki" (Kaczmarczyk, Szafrańska 1985, s. 65).

Muzyka jest codziennym dobrem wszystkich ludzi, a w szczególności osób z niepełnosprawnością intelektualną. Dźwięk każdego instrumentu ma wyjątkową zdolność wzbudzania emocji. Dociera do głębi duszy i skłania do przybrania wobec życia postawy pełnej umiaru i harmonii. Będąc sprawcami i bezpośrednimi odbiorcami dźwięku, osoby z niepełnosprawnością intelektualną zaczynały być twórcami dzieła muzycznego. Odczuwały muzykę ciałem, sercem i myślą, a przeżycia rodziły w nich pragnienie wypowiadania się i przekazywania własnych wzruszeń. Muzyczna działalność zespołowa „dostarczyła jej uczestnikom (a także słuchaczom) wielu niezapomnianych przeżyć. Artystyczna atmosfera zespołu sprawiła, że jego członkowie czuli się ze sobą silnie związani. Stworzyły się bezinteresowne więzi społeczne koleżeństwa i przyjaźni, wytworzyło się poczucie świadomej dyscypliny i współodpowiedzialności za wykonaną pracę" (Rogalski 1979, s. 35).

Teatr osób z niepełnosprawnością intelektualną jako sztuka wrażliwa ,jest nerwowy, wymaga opieki niejako ogrodowej, gdzie każda niemal roślina zasługuje na uwagę, wymaga dyscypliny, ale i wolności, nie może być urzędem, ani przedsiębiorstwem, a potrzebuje jednak realnej gospodarki, nie można go wciskać przemocą w jakieś ogólne, mechaniczne planowanie, ale trzeba go mimo to silnie związać z całokształtem prac społecznych" (Jaracz 1945, s. 21). Animacje teatralne realizowane przez osoby z niepełnosprawnością intelektualną pobudzają i dynamizują w widzu wrażliwość estetyczną, ciekawość, skłaniają do analizowania zjawisk znanych, ale zaprezentowanych w nowym świetle, tworzą głębszą więź egzystencjalną ze studentami poprzez czas i przestrzeń oraz akceptowanie różnych 
wariantów rzeczywistości. Zatem aktywność teatralna osób z niepełnosprawnością intelektualną, choć jest innym gatunkiem twórczości artystycznej i nie może zastąpić ani literatury, ani poezji, ani też być substytutem rzeźby czy malarstwa, to poszerza ludzką wrażliwość i materializuje to, co tkwi w człowieczym wnętrzu.

Przedstawione formy działalności artystycznej osób z niepełnosprawnością intelektualną oraz studentów wykreowały nową rzeczywistość zatytułowaną „Majówka Aniołów”. Coroczne wydarzenie animacyjne jest efektem twórczej współpracy kilku środowisk, a mianowicie: uczniów z Zespołu Szkół z Oddziałami Integracyjnymi im. Stefana Kisielewskiego w Warszawie, uczniów z Zespołu Szkół Specjalnych nr 90 w Warszawie, księży z parafii Najczystszego Serca Maryi w Warszawie oraz studentów Wydziału Nauk Pedagogicznych Uniwersytetu Kardynała Stefana Wyszyńskiego w Warszawie. Zarówno dla uczniów, jak i dla studentów jest to twórcze spotkanie, przeciwstawiające się z jednej strony utrwalonym schematom, a z drugiej - jakimkolwiek formom arteterapii. Należy je traktować jako proces tworzenia mający związek z ludycznością i polegający na wspólnym czerpaniu ze źródeł pozytywnych doświadczeń.

\section{Wnioski do dyskusji}

Za fundament arteterapii uznaję spektrum działań artystyczno-estetycznych w wymiarze psychologicznym, pedagogicznym i socjologicznym, skoncentrowanych na przywróceniu jednostce zdrowia, równowagi psychicznej, wiary w życie i jego sens. Aby powyższe warunki mogły być spełnione, arteterapia musi stanowić medium komunikacji, być środkiem autorefleksji zmierzającej do budowania indywidualnej i społecznej ścieżki doskonalenia. Choć oddziaływanie arteterapeutyczne uważam za niezwykle ważne i cenne w pracy z jednostką z niepełnosprawnością, to w niniejszym artykule podjęłam próbę ukazania działań artystycznych osób z niepełnosprawnością intelektualną w połączeniu z działaniami artystycznymi studentów, które akcentują inny, odmienny niż arteterapeutyczny, a może po prostu zwyczajny wymiar tworzenia plastycznego, muzycznego i teatralnego.

Wnioski są następujące:

1. Aktywność artystyczna osób z niepełnosprawnością intelektualną oraz studentów ma prawo nie koncentrować się na problemach, niedoskonałościach, cierpieniach - niepełnosprawności podmiotu, ale może wprowadzać go w świat twórczości. Warto podkreślić, że aktywność artystyczna nie stanowiła wymiaru katarktycznego, a stworzone dzieło pt. „Majówka Aniołów” nie prowadziło do analiz, a tym bardziej nie wskazywało na istniejący związek między przeszłością a teraźniejszością w życiu jego autorów.

2. Niezbędne jest ukazywanie obrazu jednostki z niepełnosprawnością intelektualną, której funkcjonowanie nie musi i nie powinno być przesycone wartościami arteterapeutycznymi (leczniczymi, kompensacyjnymi, katarktycznymi), tym bardziej że w literaturze przedmiotu tak wiele miejsca poświęca się pojęciu normalizacji życia takich osób. 
3. Działania artystyczne były współorganizowane i współprowadzone przez studentów Wydziału Nauk Pedagogicznych Uniwersytetu Kardynała Stefana Wyszyńskiego w Warszawie - ludzi młodych, radosnych, nieposiadających kwalifikacji zawodowych ani kompetencji warsztatowych w wybranej dziedzinie sztuki (kompetencji arteterapeutycznych), lecz mających na celu normalizację wzajemnego funkcjonowania poprzez bezpośrednią inspirację.

4. Jeśli każde działanie twórcze osób z niepełnosprawnością intelektualną w dziedzinie plastyki, muzyki czy teatru uznamy za arteterapeutyczne, to każde wytworzone w tym procesie dzieło przybierze wyłącznie charakter terapeutyczny, a nie artystyczny.

5. „Z kreacją artystyczną jako terapią mamy do czynienia wtedy, gdy ktoś świadomie podejmuje ją w celach terapeutycznych (przez co posiada ona określony cel i przebieg). Zdarza się, że twórczość plastyczna odbywa się pomiędzy sesjami terapeutycznymi lub po zakończeniu terapii jako pewna jej kontynuacja. Taka forma terapeutycznej kreacji występuje w nurcie arteterapeutycznym zwanym sztuka jako terapia, który czasami bywa mylony ze zwykłą twórczością plastyczną, pełniącą jakoby funkcję terapeutyczną" (Popek 2010, s. 432). Nawiązując do sztuki jako terapii, prof. Andrzej Wojciechowski nadmienia, że wielkim lękiem napawa postulat, by sztuka w całej swojej złożoności pełniła rolę terapeutyczną (Wojciechowski 1994).

Niniejszy artykuł jest tego wyrazem.

\section{Bibliografia}

Aumer B. (1995). Sztuka jest jedna. Twórczość niepełnosprawnych. Warszawa: Wydawnictwo WSiP.

Dacey J.S., Lennon K.H. (1998). Understanding creativity. The interplay of biological, psychological and social factors. San Francisco: Jossey-Bass.

Jaracz S. (1945). O styl teatru polskiego. „Nowa Epoka”, nr 6, s. 21.

Kaczmarczyk B., Szafrańska D. (1985). Stymulowanie twórczej aktywności muzycznej i plastycznej dzieci sześcioletnich w przedszkolu. „Kwartalnik Pedagogiczny”, nr 1, s. 65.

Krasoń K., Mazepa-Domagała B. (2003). Przestrzenie sztuki dziecka. Strategia intersemiotycznego i polisensorycznego wsparcia jednostek o obniżonej sprawności intelektualnej. Katowice: Wydawnictwo Librus.

Krauze-Sikorska H. (2006). Edukacja przez sztukę. O edukacyjnych wartościach artystycznej twórczości dziecka. Poznań: Wydawnictwo UAM.

Lam W. (1960). Sztuka dziecka i jej naturalny rozwój. Warszawa: Wydawnictwo Nasza Księgarnia.

Maslow A.H. (1986). W strone psychologii istnienia. Warszawa: Wydawnictwo Pax. Mrozkowiak-Nastrożna N. (2006). Dążenia twórcze jako budowanie tożsamości współczesnego człowieka. W: Limont W., Nielek-Zawadzka K. (red.). Dylematy 
edukacji artystycznej. Edukacja artystyczna a potencjał twórczy człowieka. Kraków: Oficyna Wydawnicza Impuls.

Okoń W. (1992). Słownik pedagogiczny. Warszawa: PWN.

Ploch L. (2014). Konteksty aktywności artystycznej osób z niepełnosprawnościa. Warszawa: Difin.

Popek S. (2010). Psychologia twórczości plastycznej. Kraków: Oficyna Wydawnicza Impuls.

Rogalski E. (1979). Funkcje wychowawcze amatorskiego ruchu chóralnego. Bydgoszcz: Wydawnictwo WSP.

Schulz R. (1990). Twórczość - społeczne aspekty zjawiska. Warszawa: PWN.

Stańko-Kaczmarek M. (2013). Arteterapia i warsztaty edukacji twórczej. Warszawa: Wydawnictwo Difin.

Szmidt K.J. (2013). Pedagogika twórczości. Sopot: Gdańskie Wydawnictwo Psychologiczne.

Wojciechowski A. (1994). Terapia przez twórczość - elementy do teorii. W: Pedagogika. Acta Uniwersitatis Nicolai Copernici, t. 20. Toruń: Wydawnictwo UMK.

Zinker J. (1991). Proces twórczy w terapii gestalt. Warszawa: Wydawnictwo Jacek Santorski \& Co.

\title{
ARTISTIC ACTIVITIES OF SCHOOLCHILDREN WITH INTELLECTUAL DISABILITIES AND STUDENTS - AS A NEGATION OF ART THERAPY
}

\begin{abstract}
The study aims to present artistic activities of schoolchildren with intellectual disabilities and students in the area of casual, amateur fine arts, music and theatre. It presents the possibility of using the need of expression, which is opposed to the nature of art therapy. The content of the text was enhanced by personal observations and thoughts arising from artistic work with people with intellectual disabilities.
\end{abstract}

Key words: creativity, creative activity of people with intellectual disabilities, art therapy, art, music, theatre

Kinga Krawiecka - doktor nauk humanistycznych w dyscyplinie pedagogika, adiunkt w Katedrze Pedagogiki Specjalnej, Przedszkolnej i Wczesnoszkolnej WNP UKSW. Zainteresowania naukowe: pedagogika osób z niepełnosprawnością intelektualną, metodyka pracy z osobami z niepełnosprawnością intelektualną, praca dydaktyczna, rehabilitacyjna i terapeutyczna $\mathrm{z}$ osobami z niepełnosprawnością intelektualną, działalność artystyczna: w szczególności plastyczny i teatralny wymiar procesu tworzenia i odtwarzania w działalności pedagogicznej z jednostkami z niepełnosprawnością intelektualną. Autorka monografii Realizm intelektualny a realizm wizualny $w$ działalności plastycznej osób zniepetnosprawnością intelektualną (2014). Adres e-mail: k.krawiecka@uksw.edu.pl. 